\title{
Positive versus normative economics: what's the connection? Evidence from the Survey of Americans and Economists on the Economy and the General Social Survey
}

\author{
Bryan Caplan • Stephen C. Miller
}

Received: 28 May 2009 / Accepted: 1 August 2010

(C) Springer Science+Business Media, LLC 2010

\begin{abstract}
Previous research suggests that positive and normative beliefs about economics are largely unrelated. Using questions from two national surveys, this study finds that: (a) the underlying determinants of positive and normative beliefs are strikingly similar; (b) education is by far the strongest overall determinant of both positive and normative beliefs; and (c) the variables known to push positive beliefs in the same direction as formal economic training-education, male gender, income growth, and job security-also push normative beliefs in the same direction. These results strongly suggest that the positive-normative connection has been underestimated.
\end{abstract}

Keywords Economic beliefs · Positive economics · Normative economics

JEL Classification D83 - A11 - D84

\section{Introduction}

Beliefs about positive economics and normative economics are logically distinct. A person who holds the normative belief that free trade is good does not have to accept the positive belief that free trade promotes growth. He might even favor free trade on the grounds that growth is $b a d$, and free trade retards growth. Nevertheless, economists often assume that positive and normative beliefs are closely connected. Milton Friedman provides the canonical statement of this position:

\section{B. Caplan}

Department of Economics, Center for Study of Public Choice, and Mercatus Center,

George Mason University, Fairfax, USA

e-mail: bcaplan@gmu.edu

S.C. Miller (凶)

Western Carolina University, Cullowhee, USA

e-mail: smiller@wcu.edu 
I venture the judgment, however, that currently in the Western world, and especially in the United States, differences about economic policy among disinterested citizens derive predominantly from different predictions about the economic consequences of taking action-differences that in principle can be eliminated by the progress of positive economics - rather than from fundamental differences in basic values, differences about which men can ultimately only fight (1953: 5).

When researchers have tested Friedman's conjecture, however, their results have been surprisingly negative (Blinder and Krueger 2004). If Friedman is right for any segment of the population, one would expect it to be his fellow economists. But in fact, economists' normative beliefs appear to be largely disconnected from their positive beliefs (Fuchs et al. 1998; Fuchs 1996; Ricketts and Shoesmith 1992). If even the experts fail to adjust their policy preferences in light of the perceived facts, what chance is there that laymen's normative beliefs "derive predominantly from different predictions about the economic consequences of taking action"?

In this paper, we perform a robustness check which suggests that previous literature underestimates the connection between positive and normative economics beliefs. Analyzing both categories of beliefs, we show that for the general public, (a) the underlying determinants of positive and normative beliefs are strikingly similar; (b) education is by far the strongest overall determinant of both positive and normative beliefs; and (c) the variables known to push positive beliefs in the same direction as formal economic trainingeducation, male gender, income growth, and job security - do the same for normative beliefs.

The key assumption of this paper is that if positive and normative economic beliefs were really unrelated, we would expect their underlying determinants to differ. Imagine, for example, if education had a large effect on positive beliefs, with no effect on normative beliefs, while income had a large effect on normative beliefs, with no effect on positive beliefs. This would support the view that positive and normative economics are disconnected. On the other hand, if education were the main determinant of both positive and normative beliefs, this would bolster the theory that the two categories of belief are intertwined.

Of course, none of our findings decisively proves that positive and normative economic beliefs are connected. Yet from a Bayesian point of view (Howson and Urbach 1989), they appreciably raise the probability of a connection. Let $P(A)$ be our prior probability that positive and normative economic beliefs are connected, and $P(A \mid B)$ be our posterior probability that positive and normative economic beliefs are connected given our main results. Our main results are clearly more likely if a genuine connection exists: $\frac{P(B \mid A)}{P(B)}>1$. Since according to Bayes' Law, $\frac{P(A \mid B)}{P(A)}=\frac{P(B \mid A)}{P(B)}$, we can infer that $\frac{P(A \mid B)}{P(A)}>1$ as well. Our findings therefore imply that a positive-normative connection is more likely to exist than it initially appeared. The stronger the findings, of course, the more likely they reflect a genuine connection rather than coincidence. ${ }^{1}$

Admittedly, if our prior probability of the hypothesis were extremely low, it might be uninteresting to discover that it is more likely than we thought. Our prior probability of a connection between normative economic beliefs and American Idol viewership, for example, is presumably trivial. ${ }^{2}$ If the underlying determinants of normative economic beliefs and American Idol viewership were similar, the hypothesis that the two are connected would become more likely, but the findings still probably wouldn't pass the "worth reporting" thresh-

\footnotetext{
${ }^{1}$ We thank an anonymous referee for suggesting this point.

${ }^{2}$ We thank an anonymous referee for suggesting an example along these lines.
} 
old. In contrast, almost all economists would assign a moderate or high prior probability to the hypothesis that positive and normative economic beliefs are connected. Since we already take this hypothesis seriously, evidence that significantly changes our posterior probability deserves our attention.

Our evidence comes from two distinct data sets: the Survey of Americans and Economists on the Economy (Washington Post, Kaiser Family Foundation, Harvard University Survey Project 1996; Blendon et al. 1997; henceforth SAEE), and the General Social Survey (2008; henceforth GSS). One of us has already extensively explored the SAEE (Caplan 2001, 2002a, 2002b, 2006, 2007). Since Caplan interpreted all of the questions on the SAEE as positive, however, none of his prior research on this data set was able to test for a connection between positive and normative beliefs. In contrast, while the General Social Survey contains questions about both positive and normative economics, researchers are only beginning to study the responses to these questions ${ }^{3}$ (Miller 2009; Caplan and Miller 2010).

Relying solely on the GSS, we can test for-and demonstrate the presence of - strong parallels between positive and normative economics. But this could merely reflect a priming effect. Positive and normative economic beliefs might seem related in the GSS because people were surveyed about both subjects at the same time (Krosnick and Alwin 1987; Foss 1982). Combining the SAEE's positive questions with the GSS's mix of positive and normative questions helps overcome this concern. Using two independent data sets, one wholly positive, the other largely normative, confirms that the positive-normative connection is as strong as you would conclude if you analyzed the GSS in isolation.

The next section discusses the two data sets. Section 3 analyzes the underlying determinants of economic beliefs. Section 4 checks whether both data sets share common sign patterns. Section 5 discusses the broader significance of the results. Section 6 concludes.

\section{Data}

Our analysis builds on two distinct data sets: the Survey of Americans and Economists on the Economy, and the General Social Survey. Since the SAEE specifically focuses on economics, we follow Caplan (2001, 2002a, 2002b, 2006, 2007) in using virtually all of the questions, 37 in total (Table 1). The GSS, on the other hand, covers literally hundreds of subjects, so we had to select a sub-set of economically relevant questions. We settled on 34 (Table 2). Both data sets have nearly identical sets of control variables (Tables 1 and 2).

Our next step was to carefully examine each question and classify it as positive or normative. We classified all 37 questions in the SAEE as positive. The questions about whether $X$ is "good or bad for the nation's economy" are the toughest call. In our judgment, however, they are as empirically testable as questions about whether a drug is good or bad for a person's health. In contrast, many of the questions in the GSS are clearly normative because they explicitly ask about desirable economic policy. In the end, we classified 11 of the 34 questions from the GSS as positive, and the rest as normative.

\footnotetext{
${ }^{3}$ Caplan (2007) briefly discusses a few questions from the GSS, but does not systematically study its questions about economics or econometrically analyze the responses.
} 
Table 1 SAEE questions and control variables

\begin{tabular}{|c|c|c|}
\hline Variable & Question & Mean \\
\hline \multicolumn{3}{|c|}{ Positive questions } \\
\hline \multicolumn{3}{|c|}{$\begin{array}{l}\text { Regardless of how well you think the economy is doing, there are always some problems that keep it from } \\
\text { being as good as it might be. I am going to read you a list of reasons some people have given for why the } \\
\text { economy is not doing better than it is. For each one, please tell me if you think it is a major reason the } \\
\text { economy is not doing better than it is, a minor reason, or not a reason at all. }\end{array}$} \\
\hline & \multicolumn{2}{|l|}{$0=$ "Not a reason at all"; $1=$ "Minor reason"; } \\
\hline & \multicolumn{2}{|l|}{$2=$ "Major reason" } \\
\hline Taxhigh & Taxes are too high & 1.50 \\
\hline Deficit & The federal deficit is too big & 1.73 \\
\hline Foraid & Foreign aid spending is too high & 1.53 \\
\hline Immig & There are too many immigrants & 1.23 \\
\hline Taxbreak & Too many tax breaks for business & 1.29 \\
\hline Inadeduc & Education and job training are inadequate & 1.56 \\
\hline Welfare & Too many people are on welfare & 1.61 \\
\hline Aa & Women and minorities get too many advantages under affirmative action & 0.75 \\
\hline Hardwork & People place too little value on hard work & 1.43 \\
\hline Reg & The government regulates business too much & 1.22 \\
\hline Savings & People are not saving enough & 1.39 \\
\hline
\end{tabular}

Now I am going to read you another list of reasons, having to do with business, that some people have given for why the economy is not doing better than it is. For each one, please tell me if you think it is a major reason the economy is not doing better than it is, a minor reason, or not a reason at all.

$0=$ "Not a reason at all"; $1=$ "Minor reason";

$2=$ "Major reason"

\begin{tabular}{llr}
\hline Profhigh & Business profits are too high & 1.27 \\
Execpay & Top executives are paid too much & 1.60 \\
Busprod & Business productivity is growing too slowly & 1.19 \\
Tech & Technology is displacing workers & 1.26 \\
Overseas & Companies are sending jobs overseas & 1.59 \\
Downsize & Companies are downsizing & 1.51 \\
Compeduc & Companies are not investing enough money in education and job training & 1.55 \\
\hline
\end{tabular}

Generally speaking, do you think each of the following is good or bad for the nation's economy, or don't you think it makes much difference?

$0=$ "Bad"; 1 = "Doesn't make much difference"; 2 = "Good"

\begin{tabular}{llr}
\hline Taxcut & Tax cuts & 1.47 \\
womenwork & More women entering the workforce & 1.48 \\
Techgood & Increased use of technology in the workforce & 1.57 \\
Tradeag & Trade agreements between the United States and other countries & 1.34 \\
Downgood & The recent downsizing of large corporations & 0.60 \\
\hline
\end{tabular}

Some people say that these are economically unsettled times because of new technology, competition from foreign countries, and downsizing. Looking ahead 20 years, do you think these changes will eventually be good or bad for the country or don't you think these changes will make much difference?

$\begin{array}{lll}\text { change20 } & 0=\text { "Bad"; } 1 \text { = "Won't make much of a difference"; } 2 \text { = "Good" } & 1.15\end{array}$


Table 1 (Continued)

Variable Question $\quad$ Mean

Do you think that trade agreements between the United States and other countries have helped create more jobs in the U.S., or have they cost the U.S. jobs, or haven't they made much of a difference?

\begin{tabular}{lll}
\hline Tradejob & $0=$ "Cost the U.S. jobs"; 1 = "Haven't made much difference"; & 0.64 \\
2 & $=$ "Helped create jobs in the U.S".
\end{tabular}

Which do you think is more responsible for the recent increase in gasoline prices?

\begin{tabular}{lll}
\hline Whygassd & $0=$ "Oil companies trying to increase their profits"; $1=$ "The normal law of & 0.26 \\
& supply and demand" ["both" coded as $1 ;$ "neither" as 0$]$
\end{tabular}

Do you think Improving the economy is something an effective president can do a lot about, do a little about, or is that mostly beyond any president's control?

\begin{tabular}{lll}
\hline Pres & $0=$ "Beyond any president's control"; 1 = "Do a little about"; & 0.92 \\
$2=$ "Something president can do a lot about" & \\
\hline
\end{tabular}

Do you think the current price of gasoline is too high, too low, or about right?

Gasprice $\quad 0=$ "Too low"; 1 = "About right"; 2 = "Too high"

Do you think most of the new jobs being created in the country today pay well, or are they mostly low-paying jobs?

Newjob $\quad 0=$ "Low-paying jobs"; 1 = "Neither"; 2 = "Pay well"

Do you think the gap between the rich and poor is smaller or larger than it was 20 years ago, or is it about the same?

gap20 $0=$ "Smaller"; 1 = "About the same"; $2=$ "Larger" 1.70

During the past 20 years, do you think that, in general, family incomes for average Americans have been going up faster than the cost of living, staying about even with the cost of living, or falling behind the cost of living?

income20 $0=$ "Falling behind"; 1 = "Staying about even"; $2=$ "Going up"

Thinking just about wages of the average American worker, do you think that during the past 20 years they have been going up faster than the cost of living, staying about even with the cost of living, or falling behind the cost of living?

wage20 $0=$ "Falling behind"; $1=$ "Staying about even"; $2=$ "Going up" 0.34

Some people say that in order to make a comfortable living, the average family must have two full-time wage earners. Do you agree with this, or do you think the average family can make a comfortable living with only one full-time wage earner?

need2learn $\quad 0=$ "Can make living with one wage earner"; $1=$ "Agree that need two wage 0.87 earners"

Over the next five years, do you think the average American's standard of living will rise, or fall, or stay about the same?

stan5 $0=$ "Fall"; $1=$ "Stay about the same"; $2=$ "Rise"

Do you expect your children's generation to enjoy a higher or lower standard of living than your generation, or do you think it will be about the same?

Childgen $\quad 0=$ "Lower"; 1 = "About the same"; 2 = "Higher"

[If you have any children under the age of 30] When they reach your age, do you expect them to enjoy a higher or lower standard of living than you do now, or do you expect it to be about the same?

Childstan $\quad 0=$ "Lower"; 1 = "About the same"; 2 = "Higher" 1.30

When you think about America's economy today, do you think it is. . .

Curecon $\quad 0=$ "In a depression"; $1=$ "In a recession"; $2=$ "Stagnating"; $\quad 2.59$

$3=$ "Growing slowly"; $4=$ "Growing rapidly

Control variables

Age (1996-birth year)

Male $1=$ male; $0=$ female 
Table 1 (Continued)

\begin{tabular}{ll}
\hline Variable Question & Mean \\
\hline What race do you consider yourself? & 0.08 \\
\hline Black $\quad=1$ if black, 0 otherwise & 0.06 \\
Other $\quad=1$ if other non-white, 0 otherwise & -0.04 \\
\hline In politics today, do you consider yourself a Republican, a Democrat, or an Independent? & 0.04 \\
\hline Partyid "Democrat" = -1 ; "Independent" = 0; "Republican" = 1 & \\
\hline Othparty $\quad=1$ if other party, 0 otherwise &
\end{tabular}

Would you say that your views in most political matters are very liberal, liberal, moderate, conservative, or very conservative?

\begin{tabular}{llr}
\hline Ideology & $-2=$ "Very liberal"; $-1=$ "Liberal"; $0=$ "Moderate"; $1=$ "Conservative"; & 0.14 \\
$2=$ "Very conservative"; $3=$ "Don"t think in those terms" & 0.02 \\
othideology & $=1$ if ideology $=3,0$ otherwise \\
\hline How concerned are you that you or someone else in your household will lose their job in the next year? & 1.89 \\
\hline $\begin{array}{l}\text { Jobsec } \\
\text { concerned"; } 3=\text { "Nery concerned"; } 1=\text { "Somewhat concerned"; } 2=\text { "Not too }\end{array}$
\end{tabular}

If you added together the yearly incomes, before taxes, of all the members of your household for the last year, 1995, would the total be:

Income $\quad \begin{aligned} & 1=\$ 10,000 \text { or less } \\ & 2=\$ 10,000-\$ 19,999 \\ & 3=\$ 20,000-\$ 24,999 \\ & 4=\$ 25,000-\$ 29,999 \\ & 5=\$ 30,000-\$ 39,999 \\ & 6=\$ 40,000-\$ 49,999 \\ & 7=\$ 50,000-\$ 74,999 \\ & 8=\$ 75,000-\$ 99,999 \\ & 9=\$ 100,000 \text { or more }\end{aligned}$

During the past five years, do you think that your family's income has been going up faster than the cost of living, staying about even with the cost of living, or falling behind the cost of living?

\begin{tabular}{|c|c|c|}
\hline \multirow[t]{3}{*}{ Income growth } & $0=$ "Falling behind" & 0.75 \\
\hline & $1=$ "Staying about even" & \\
\hline & $2=$ "Going up" & \\
\hline
\end{tabular}

What is the last grade or class that you COMPLETED in school?

\begin{tabular}{ll}
\hline Education & $=$ "None, or grades 1-8" \\
2 & $=$ "High school incomplete (grades 9-12)" \\
3 & $=$ "High school graduate (grade 12 or GED certificate)" \\
4 & $=$ "Business, technical, or vocational school AFTER high school" \\
5 & $=$ "Some college, no 4-year degree" \\
6 & $=$ "College graduate (B.S., B.A., or other 4-year degree)" \\
7 & $=$ "Post-graduate training or professional schooling after college \\
& (e.g., toward a master's degree or Ph.D.; law or medical school)"
\end{tabular}

\section{Determinants of economic beliefs in the SAEE and GSS}

Most studies of positive versus normative economic beliefs directly test for a connection between the two. While this has obvious advantages, it is also very limiting. If each normative belief depends upon a long list of noisily measured positive beliefs, for example, simple 
Table 2 GSS questions and control variables

\begin{tabular}{llr}
\hline Variable Question & Mean \\
\hline
\end{tabular}

Normative questions

Here are some things the government might do for the economy. Circle one number for each action to show whether you are in favor of it or against it.

$1=$ "Strongly in favor of"; 2 = "In favor of";

$3=$ "Neither in favor nor against"; $4=$ "Against"; $5=$ "Strongly against"

\begin{tabular}{llr}
\hline Setwage & Control of wages by legislation. & 3.34 \\
Setprice & Control of prices by legislation. & 3.08 \\
Lessreg & Less government regulation of business. & 2.60 \\
\hline
\end{tabular}

On the whole, do you think it should or should not be the government's responsibility to...

$1=$ "Definitely should be"; 2 = "Probably should be";

$3=$ "Probably should not be"; 4 = "Definitely should not be"

\begin{tabular}{llr}
\hline Pricecon & Keep prices under control. & 2.10 \\
Aidindus & Provide industry with the help it needs to grow. & 2.23 \\
Reqinfo & It is the responsibility of government to require businesses to provide & 2.22 \\
& consumers with the information they need to make informed choices. \\
& $1=$ "Agree strongly"; 2 = "Agree somewhat"; \\
& $3=$ "Disagree somewhat"; 4 = "Disagree strongly" \\
\hline
\end{tabular}

What do you think the government's role in each of these industries should be.

$1=$ "Own it"; 2 = "Control prices and profits but not own it";

$3=$ "Neither own it nor control its prices and profits"

\begin{tabular}{ll}
\hline Ownpower & Electric power. \\
Ownsteel & The steel industry. \\
Ownbanks & Banking and insurance. \\
Econsys & On the whole, do you think our economic system is. . \\
& $1=$ "The best system we could possibly have"; \\
& $2=$ "Basically okay but in need of some tinkering?"; \\
& $3=$ "In need of some fundamental changes?"; \\
& $4=$ "Needing to be replaced by some other system?"
\end{tabular}

Buspow How about business and industry, do they have too much power or too little power?

$1=$ "Far too much power"; 2 = "Too much power";

$3=$ "About the right amount of power";

4 = "Too little power"; 5 = "Far too little power"

Privent Private enterprise is the best way to solve America's economic problems.

$1=$ "Strongly agree"; 2 = "Agree"; 3 = "Neither agree nor disagree";

$4=$ "Disagree"; $5=$ "Strongly disagree"

To what extent do you agree or disagree with the following statements?

$1=$ "Strongly agree"; 2 = "Agree"; 3 = "Disagree"; 4 = "Strongly disagree"

profits $2 \quad$ Corporations should pay more of their profits to workers and less to shareholders.

On these cards are some opinions about the government and the economy. For each one I'd like you to tell me whether you...

$1=$ "Strongly agree"; 2 = "Somewhat agree";

$3=$ "Somewhat disagree"; 4 = "Strongly disagree"

equal7 Generally speaking, business profits are distributed fairly in the United States.


Table 2 (Continued)

\begin{tabular}{lll}
\hline Variable Question & Mean \\
\hline
\end{tabular}

Letin Do you think the number of immigrants from foreign countries who are permitted to come to the United States to live should be. .

$1=$ "Increased a lot"; 2 = "Increased a little"; 3 = "Left the same as it is now"; 4 = "Decreased a little"; $5=$ "Decreased a lot"

Imports America should limit the import of foreign products in order to protect its national economy

$1=$ "Strongly agree"; 2 = "Agree"; 3 = "Neither agree nor disagree";

4 = "Disagree"; 5 = "Strongly disagree"

Excldimm America should take stronger measures to exclude illegal immigrants.

$1=$ "Agree strongly"; 2 = "Agree somewhat";

$3=$ "Neither agree nor disagree";

4 = "Disagree somewhat"; 5 = "Disagree strongly"

Here are some things the government might do for the economy. Circle one number for each action to show whether you are in favor of it or against it.

$1=$ "Strongly in favor of"; 2 = "In favor of";

$3=$ "Neither in favor nor against"; 4 = "Against"; $5=$ "Strongly against"

\begin{tabular}{llr}
\hline Makejobs & Government financing of projects to create new jobs. & 2.16 \\
Cuthours & Reducing the work week to create more jobs. & 3.21 \\
Savejobs & Supporting declining industries to protect jobs. & 2.62 \\
\hline
\end{tabular}

On the whole, do you think it should or should not be the government's responsibility to...

$1=$ "Definitely should be"; 2 = "Probably should be";

3 = "Probably should not be"; 4 =Definitely should not be"

Jobsall Provide a job for everyone who wants one.

On these cards are some opinions about the government and the economy. For each one I'd like you to tell me whether you...

$1=$ "Strongly agree"; 2 = "Somewhat agree";

$3=$ "Somewhat disagree"; 4 = "Strongly disagree"

equal3 The government must see to it that everyone has a job and that prices are

stable, even if the rights of businessmen have to be restricted.

Now I'd like your opinions on a number of different things.

$1=$ "Agree"; 2 = "Disagree"

\begin{tabular}{lll}
\hline anomia6 It's hardly fair to bring a child into the world with the way things look for the & 1.60
\end{tabular}
future.

Positive questions

To what extent do you agree or disagree with the following statements?

1 = "Strongly agree"; 2 = "Agree"; 3 = "Disagree"; 4 = "Strongly disagree"

profits1 The way most companies work, the only thing management cares about is 2.08 profits, regardless of what workers want or need.

On these cards are some opinions about the government and the economy. For each one I'd like you to tell me whether you...

$1=$ "Strongly agree"; 2 = "Somewhat agree";

$3=$ "Somewhat disagree"; 4 = "Strongly disagree"

equal2 The economy can run only if businessmen make good profits. That benefits everyone in the end. 
Table 2 (Continued)

\begin{tabular}{llr}
\hline Variable & Question & Mean \\
\hline Bosswrks & $\begin{array}{l}\text { There will always be conflict between management and workers because they } \\
\text { are really on opposite sides } \\
1=\text { "Strongly agree"; } 2=\text { "Agree"; } 3=\text { "Neither agree nor disagree"; } \\
4=\text { "Disagree"; } 5=\text { "Strongly disagree" }\end{array}$ \\
\hline
\end{tabular}

What do you think will happen as a result of more immigrants coming to this country? Is each of these possible results...

$1=$ "Very likely"; 2 = "Somewhat likely"; $3=$ "Not too likely"; $4=$ "Not at all likely"

\begin{tabular}{lll}
\hline immunemp Higher unemployment & 1.56
\end{tabular}

How much do you agree or disagree with each of the following statements?

$1=$ "Agree strongly"; 2 = "Agree somewhat";

$3=$ "Neither agree nor disagree"; $4=$ "Disagree somewhat"; $5=$ "Disagree strongly"

\begin{tabular}{llr}
\hline immameco & Immigrants are generally good for America's economy & 2.98 \\
nafta2alt & Generally speaking, would you say that America benefits or does not benefit & 1.91 \\
& from being a member of NAFTA?
\end{tabular}
from being a member of NAFTA?

$1=$ "Benefits"; 2 = "Don't know"; 3 = "Does not benefit"

Newpast How about the economy. Would you say that over the past year the nation's economy has...

$1=$ "Gotten much better"; 2 = "Gotten somewhat better";

$3=$ "Stayed the same";

$4=$ "Gotten somewhat worse"; $5=$ "Gotten much worse"

Newfutr What about the next 12 months? Do you expect the national economy to...

$1=$ "Get much better"; 2 = "Get somewhat better"; 3 = "Stay the same";

$4=$ "Get somewhat worse"; $5=$ "Get much worse"

On these cards are some opinions about the government and the economy. For each one I'd like you to tell me whether you...

$1=$ "Strongly agree"; 2 = "Somewhat agree";

$3=$ "Somewhat disagree"; 4 = "Strongly disagree"

equal6 All in all, one can live well in America.

Now I'd like your opinions on a number of different things.

$1=$ "Agree"; 2 = "Disagree"

\begin{tabular}{lll}
\hline anomia5 & In spite of what some people say, the lot (situation/condition) of the average & 1.38
\end{tabular} man is getting worse, not better.

Kidssol When your children are at the age you are now, do you think their standard of living will be... than yours is now?

$1=$ "Much better"; 2 = "Somewhat better";

$3=$ "About the same"; $4=$ "Somewhat worse"; $5=$ "Much worse"

Control variables

\begin{tabular}{lll}
\hline Age $\quad$ (year of survey-birth year) & 45.21 \\
Male $\quad 1=$ male; 0 = female & 0.44 \\
\hline What race do you consider yourself? & 0.14 \\
\hline Black $\quad=1$ if black, 0 otherwise & 0.03 \\
Othrace $\quad=1$ if other race, 0 otherwise
\end{tabular}

Generally speaking, do you usually think of yourself as a Republican, Democrat, Independent, or what?

\begin{tabular}{lll}
\hline Othparty $\quad=1$ if other party/refused to say & 0.01 \\
\hline
\end{tabular}


Table 2 (Continued)

\begin{tabular}{lll}
\hline Variable & Question & Mean \\
\hline partyid* & $0=$ Strong democrat; $1=$ Not very strong Democrat; $2=$ Independent, close & \\
(1-othparty) & to Democrat; $3=$ Independent; $4=$ Independent, close to Republican; & \\
& $5=$ Not very strong Republican; $6=$ Strong Republican & 2.65 \\
\hline
\end{tabular}

We hear a lot of talk these days about liberals and conservatives. I'm going to show you a seven-point scale on which the political views that people might hold are arranged from extremely liberal — point 1 - to extremely conservative-point 7 . Where would you place yourself on this scale?

\begin{tabular}{ll}
\hline Ideology & $=$ "Extremely liberal" \\
2 & $=$ "Liberal" \\
3 & $=$ "Slightly liberal" \\
4 & $=$ "Moderate" \\
5 & $=$ "Slightly conservative" \\
6 & $=$ "Conservative" \\
7 & $=$ "Extremely conservative" \\
Family income in 1986 dollars & $30,954.27$ \\
Income & \\
\hline During the last few years, has your financial situation been getting better, worse, or has it stayed the same? & 2.18 \\
\hline Income growth 1 & $=$ "Getting worse" \\
2 & $=$ "Stayed the same" \\
3 & $=$ "Getting better"
\end{tabular}

Thinking about the next 12 months, how likely do you think it is that you will lose your job or be laid off-very likely, fairly likely, not too likely, or not at all likely?

\begin{tabular}{llc}
\hline job security & 1 = "Very likely" & 3.49 \\
& $2=$ "Fairly likely" \\
3 & $=$ "Not too likely" \\
& $4=$ "Not at all likely" & 12.54 \\
Education & Years of schooling completed & 1987.41 \\
Year & Year in which question was asked & \\
Derived from GSS variable identifiers AGE, SEX, RACE, PARTYID, POLVIEWS, REALINC, FINALTER, &
\end{tabular}

regressions of normative beliefs on a few positive beliefs may not find much. Our alternative is to take an indirect approach. Rather than regress normative economic beliefs on positive economic beliefs, we regress both kinds of beliefs on a shared set of personal characteristics that seem likely to influence what people think.

Both the SAEE and the GSS measure many relevant personal characteristics. Both data sets include basic demographics—age, sex, and race; material interests—income, income growth, and job security; abstract ideas-party identification and professed ideology; and finally, education. ${ }^{4}$

Before comparing the results for the two data sets, however, it is worth comparing the results for positive versus normative beliefs within the GSS. We estimate each of the GSS's 34 questions as ordered logits, with age, age squared, sex, race (dummies for black and

\footnotetext{
${ }^{4}$ Caplan (2002b) argues that, after controlling for income, income growth, and job security, education should be interpreted as a measure of intellectual orientation rather than material interests. For purposes of the current paper, however, we can be agnostic on this point.
} 
Table 3 Positive versus normative economic beliefs in the GSS

${ }^{\mathrm{a}}$ Job security data only available for 9 out of 11 questions; $\lambda \sim \chi^{2}(18)$

${ }^{\mathrm{b}}$ Job security data only available for 21 out of 23 questions; $\lambda \sim \chi^{2}(42)$

\begin{tabular}{|c|c|c|c|c|}
\hline \multicolumn{5}{|c|}{ GSS-Pos (11 questions) } \\
\hline Variable & $p \leq 0.05$ & $p \leq 0.01$ & $p \leq 0.001$ & $\Lambda \sim \chi^{2}(22)$ \\
\hline Age & 3 & 2 & 1 & 62.81 \\
\hline $\mathrm{Age}^{2}$ & 2 & 2 & 1 & 62.30 \\
\hline Male & 5 & 3 & 1 & 72.28 \\
\hline Black & 4 & 2 & 2 & 63.30 \\
\hline Other non-white & 3 & 2 & 1 & 55.07 \\
\hline Income & 1 & 1 & 1 & 37.54 \\
\hline Income growth & 4 & 4 & 1 & 158.45 \\
\hline Job security ${ }^{a}$ & 2 & 1 & 1 & 43.05 \\
\hline Party ID & 4 & 4 & 3 & 98.15 \\
\hline Other party & 1 & 1 & & 35.43 \\
\hline Ideology & 2 & 2 & 1 & 42.28 \\
\hline Education & 8 & 8 & 6 & 173.91 \\
\hline \multicolumn{5}{|c|}{ GSS-Norm (23 questions) } \\
\hline Variable & $p \leq 0.05$ & $p \leq 0.01$ & $p \leq 0.001$ & $\Lambda \sim \chi^{2}(46)$ \\
\hline Age & 4 & 3 & 1 & 83.59 \\
\hline $\mathrm{Age}^{2}$ & 4 & 2 & 1 & 67.32 \\
\hline Male & 9 & 7 & 4 & 202.53 \\
\hline Black & 10 & 7 & 5 & 291.86 \\
\hline Other non-white & 9 & 5 & 2 & 152.40 \\
\hline Income & 11 & 8 & 6 & 215.62 \\
\hline Income growth & 4 & 3 & 1 & 82.70 \\
\hline Job security ${ }^{b}$ & 2 & & & 60.38 \\
\hline Party ID & 15 & 15 & 10 & 379.05 \\
\hline Other party & 7 & 2 & & 88.50 \\
\hline Ideology & 18 & 14 & 12 & 359.65 \\
\hline Education & 18 & 16 & 15 & 813.17 \\
\hline
\end{tabular}

"other", with white as the omitted category), income, income growth, job security, party (plus a dummy variable for those who identify with third parties), ideology, and education as independent variables.

Table 3 summarizes the results showing (a) the number of questions where each independent variable is statistically significant at the $5 \%, 1 \%$, and $0.1 \%$ levels, and (b) each independent variable's $p_{\lambda}$ statistic - a measure of an independent variable's overall importance in a system of equations (Maddala 1977: 47-48). ${ }^{5}$

The predictors of positive and normative beliefs have several prominent similarities. As measured by its $\lambda$, education is the strongest predictor of both positive and normative economic beliefs. It has a statistically significant effect in 8 out of the 11 positive questions, and 18 out of the 23 normative questions. If one separately lists the six strongest predictors of the two kinds of beliefs, they have four in common: education, party identification, being male,

\footnotetext{
${ }^{5}$ Question-by-question results are available from the authors upon request.
} 
Table 4 Summary results for positive economic beliefs

\begin{tabular}{lcccl}
\hline \multicolumn{5}{l}{ SAEE + GSS-Pos (48 questions $)$} \\
Variable & $p \leq 0.05$ & $p \leq 0.01$ & $p \leq 0.001$ & $\Lambda \sim \chi^{2}(96)$ \\
\hline Age & 17 & 11 & 7 & 301.58 \\
Age $^{2}$ & 14 & 11 & 8 & 292.32 \\
Male & 26 & 18 & 10 & 430.57 \\
Black & 12 & 7 & 6 & 259.4 \\
Other non-white & 8 & 5 & 3 & 183.39 \\
Income & 7 & 2 & 2 & 141.12 \\
Income growth & 22 & 19 & 12 & 657.97 \\
Job security & 20 & 12 & 7 & 321.46 \\
Party ID & 17 & 15 & 6 & 328.24 \\
Other party & 2 & 1 & & 107.68 \\
Ideology & 16 & 16 & 13 & 443.45 \\
Education & 31 & 27 & 22 & 901.77 \\
\hline
\end{tabular}

and being black. The correlation between the vector of $p_{\lambda}$ statistics for normative beliefs and the vector of $p_{\lambda}$ statistics for positive beliefs is 0.55 . $^{6}$

One could reply, however, that the intra-GSS parallels are unconvincing. When the GSS asks the same people about normative and positive beliefs, isn't it "leading the witness"? The parallels in the data could stem from a priming effect-people trying to make their answers more internally consistent than their actual beliefs (Krosnick and Alwin 1987).

We leverage the SAEE to deal with this concern. To make the comparisons as consistent as possible, we estimate responses to the SAEE's questions as ordered logits, using the same set of independent variables that we used for the GSS. ${ }^{7}$ To take full advantage of available information, we pool all of the questions about positive economics- 37 from the SAEE, plus 11 from the GSS - and compare them to the GSS's normative sub-sample ${ }^{8}$ (Table 4). Once again, there are strong similarities between the underlying predictors of these two kinds of beliefs. As always, education comes out on top. Party identification, ideology, and male gender have strong effects for both categories of questions. Positive and normative economic beliefs have four out of six top predictors in common (Fig. 1).

There are also important differences. Income growth and job security have strong effects on positive economic beliefs, but little on normative economic beliefs. Income level and race have important effects on normative economic beliefs, but little on positive economic beliefs. On balance, though, the similarities overwhelm the differences: the correlation between the $p_{\lambda}$ statistics for these two categories of belief is 0.65 .

Table 5 summarizes our results so far, showing the correlation matrix for the vectors of $p_{\lambda}$ statistics derived from five distinct subsets of our seventy-one ordered logits. The five subsets are: (1) all of the normative questions in the GSS; (2) all of the positive questions in

\footnotetext{
${ }^{6}$ For consistency, all calculated correlations adjust Job Security's $\lambda$ 's to account for missing observations, but this adjustment makes almost no difference for the final results.

${ }^{7}$ To do so requires just two marginal sacrifices of available data. Since the SAEE has four racial categories (white, black, Asian, and other), and the GSS has only three (white, black, and other), consistency forces us to use the latter's breakdown for both data sets. More substantively, the SAEE measures both past and expected income growth, while the GSS measures only past income growth. Again for the sake of consistency, we drop expected income growth from the list of regressors.

${ }^{8}$ Question-by-question results are available from the authors upon request.
} 


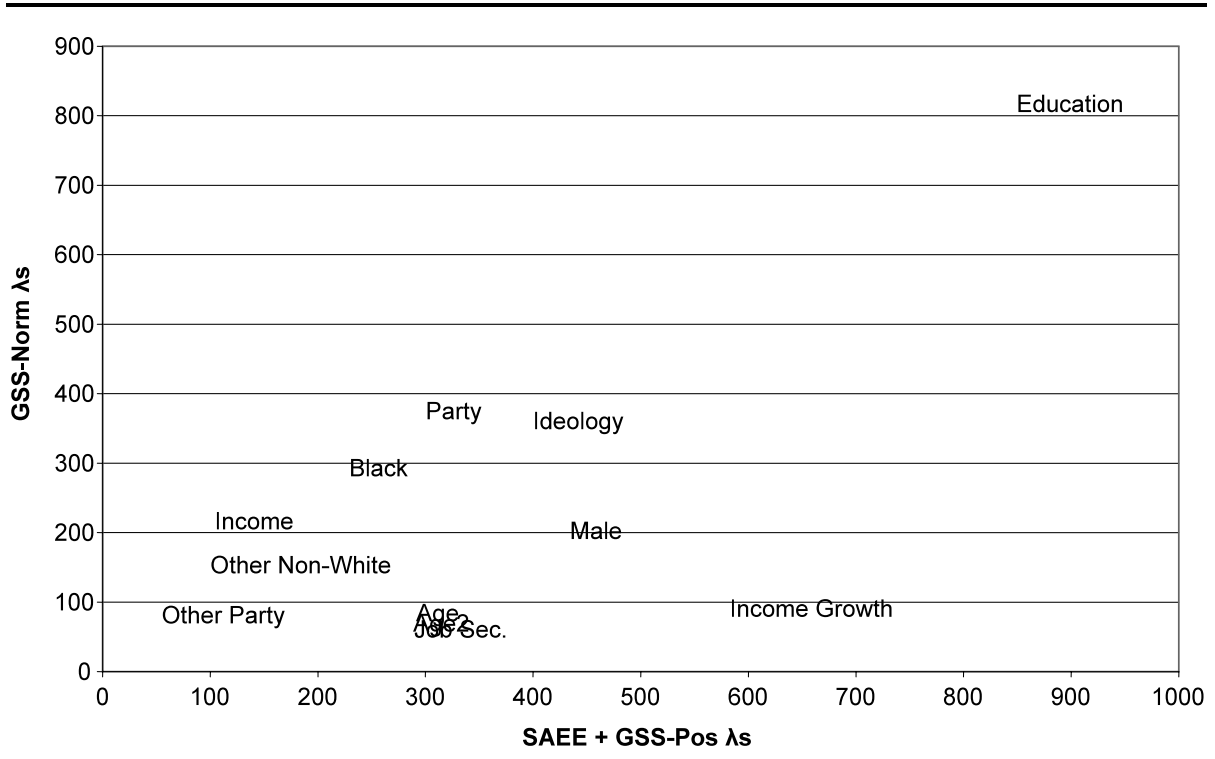

Fig. 1 Overall results for positive vs. normative economics $(r=0.65)$

Table 5 Correlations between $p_{\lambda}$ vectors

\begin{tabular}{llllll}
\hline & GSS-Norm & GSS-Pos & GSS-Total & SAEE & $\begin{array}{c}\text { SAEE }+ \\
\text { GSS-Pos }\end{array}$ \\
\hline GSS-Norm & $1.00^{* * *}$ & & & \\
GSS-Pos & $0.55^{*}$ & $1.00^{* * * *}$ & & & \\
GSS-Total & $0.99^{* * *}$ & $0.68^{* * *}$ & $1.00^{* * * *}$ & & \\
SAEE & $0.66^{* *}$ & $0.83^{* * *}$ & $0.74^{* * * *}$ & $1.00^{* * * *}$ & \\
SAEE+ & $0.65^{* *}$ & $0.89^{* * *}$ & $0.74^{* * *}$ & $0.99^{* * *}$ & $1.00^{* * *}$ \\
GSS-Pos & & & & & \\
\hline
\end{tabular}

* Significant at the $5 \%$ level

** Significant at the $1 \%$ level

*** Significant at the $0.1 \%$ level

the GSS; (3) all of the questions in the GSS; (4) all of the questions in the SAEE; and (5) all of the positive questions from either data set. Every correlation in Table 5 is positive and statistically significant; independent variables that predict beliefs in one of the five categories tend to predict beliefs in all five.

Strong positive correlations between sub-sets with many questions in common are not surprising. The more noteworthy findings are the correlations between sub-sets with no questions in common. These range from a low of 0.55 for positive versus normative beliefs within the GSS, to a high of 0.83 for positive beliefs in the GSS versus the SAEE. The most noteworthy finding of all, however, is that if you put all of the positive questions into one bundle, and all of the normative questions into another bundle, their $\lambda$ s have a correlation of 0.65 . Independent variables that predict beliefs about positive economics also have a strong tendency to predict beliefs about normative economics. 
To repeat, none of these correlations decisively prove a link between positive and normative economics. Our goal is simply to add new weight to the scales of evidence. From a Bayesian point of view, our strong, consistent findings across two distinct data sets seriously undermine the literature's recurring counter-intuitive finding that positive and normative are separate realms.

\section{Sign patterns in the SAEE and GSS}

Education is the strongest predictor of beliefs about both positive and normative economics. Party identification, ideology, and gender also appear to have a strong influence on both sorts of beliefs. These facts cast doubt on the view that positive and normative economic beliefs are disconnected. If they are, why are their underlying structures so similar?

Before drawing any conclusions, however, we should verify whether the sign patterns for positive and normative economic beliefs match up. It is not enough for a variable to exert statistically significant effects on both positive and normative economic beliefs. It is also necessary for the variable to push both sorts of beliefs in the expected direction.

For example, in the SAEE, education makes respondents more optimistic about the economic effects of overseas competition and trade agreements. ${ }^{9}$ In the GSS, similarly, education makes respondents more optimistic about the economic effects of NAFTA. ${ }^{10}$ But does education also make them more likely actually to support free trade? Since the GSS asks respondents whether "America should limit the import of foreign products in order to protect its national economy", ${ }^{11}$ we can verify that it does. At least for trade, education pushes positive and normative beliefs in the expected directions.

In most cases, however, the correspondence between positive and normative questions is less straightforward. The best that we can do is see whether sign patterns are consistent with previous research (Caplan 2001, 2002a, 2007).

Education, gender, income growth, and job security. In his analysis of the SAEE, Caplan (2001) finds that education, male gender, income growth, and job security make people "think like economists". ${ }^{12}$ Economists are dramatically less prone to what Caplan (2007) terms antimarket, antiforeign, make-work, and pessimistic conclusions. The SAEE shows that education, being male, income growth, and job security all tend to push in the same direction as economic training.

Do education, income growth, job security, and male gender work in the same directions in the GSS? More importantly, do these four variables reduce agreement with antimarket, antiforeign, make-work, and pessimistic normative beliefs? In short, do they work in an "economistic" direction? Table 6 displays the results.

The sign patterns definitely hold up for positive economic beliefs. Education pushes in an economistic direction in seven out of eleven questions, and in the opposite direction only once. Male gender, income growth, and job security push in an economistic direction five, four, and two times respectively, and never do the opposite.

For normative economic beliefs, matters are more complex. There are strong findings for education. It works in an economistic direction for 18 out of 23 normative questions, and

\footnotetext{
${ }^{9}$ SAEE variable identifiers OVERSEAS and TRADEAG.

${ }^{10} \mathrm{GSS}$ variable identifier NAFTA2ALT.

${ }^{11} \mathrm{GSS}$ variable identifier IMPORTS.

${ }^{12}$ See also Whaples (2006), Fuller and Geide-Stevenson (2003), and Alston et al. (1992).
} 
Table 6 Sign patterns in the GSS: education, male gender, income growth, job security

\begin{tabular}{|c|c|c|c|c|}
\hline GSS-normative & Education & Male & $\begin{array}{l}\text { Income } \\
\text { growth }\end{array}$ & Job security \\
\hline setwage & $\sqrt{ }$ & $\sqrt{ }$ & & \\
\hline setprice & $\sqrt{ }$ & $\sqrt{ }$ & & \\
\hline lessreg & & $\sqrt{ }$ & & \\
\hline pricecon & $\sqrt{ }$ & & & \\
\hline aidindus & $\sqrt{ }$ & & & \\
\hline \multicolumn{5}{|l|}{ reqinfo } \\
\hline ownpower & & $\times$ & & \\
\hline ownsteel & $\sqrt{ }$ & & & \\
\hline ownbanks & $\sqrt{ }$ & & & \\
\hline \multicolumn{5}{|l|}{ econsys } \\
\hline buspow & & & $\sqrt{ }$ & \\
\hline \multicolumn{5}{|l|}{ privent } \\
\hline \multicolumn{5}{|l|}{ profits2 } \\
\hline equal7 & & & & - \\
\hline letin & $\sqrt{ }$ & & & \\
\hline imports & $\sqrt{ }$ & & & \\
\hline excldimm & $\sqrt{ }$ & & & \\
\hline \multicolumn{5}{|l|}{ makejobs } \\
\hline cuthours & $\sqrt{ }$ & & & \\
\hline \multicolumn{5}{|l|}{ savejobs } \\
\hline jobsall & $\sqrt{ }$ & & & $\sqrt{ }$ \\
\hline equal3 & $\sqrt{ }$ & & $\sqrt{ }$ & - \\
\hline \multirow[t]{3}{*}{ anomia6 } & $\sqrt{ }$ & & $\sqrt{ }$ & $\sqrt{ }$ \\
\hline & $18 \sqrt{ }$ & $8 \sqrt{ }$ & $3 \sqrt{ }$ & $2 \sqrt{ }$ \\
\hline & $\mathbf{0} \times$ & $1 \times$ & $\mathbf{0} \times$ & $\mathbf{0} \times$ \\
\hline \multicolumn{5}{|l|}{ GSS-Pos } \\
\hline \multicolumn{5}{|l|}{ profits 1} \\
\hline equal2 & & $\sqrt{ }$ & & - \\
\hline bosswrks & $\sqrt{ }$ & & & \\
\hline immunemp & $\sqrt{ }$ & & & \\
\hline \multicolumn{5}{|l|}{ immameco } \\
\hline nafta2alt & $\sqrt{ }$ & & & \\
\hline \multicolumn{5}{|l|}{ newpast } \\
\hline \multicolumn{5}{|l|}{ newfutr } \\
\hline equal6 & & $\sqrt{ }$ & $\sqrt{ }$ & - \\
\hline anomia5 & $\sqrt{ }$ & & $\sqrt{ }$ & $\sqrt{ }$ \\
\hline \multirow[t]{3}{*}{ kidssol } & $\times$ & & $\sqrt{ }$ & $\sqrt{ }$ \\
\hline & $7 \sqrt{ }$ & $5 \sqrt{ }$ & $4 \sqrt{ }$ & $2 \sqrt{ }$ \\
\hline & $1 \times$ & $\mathbf{0} \times$ & $\mathbf{0}$ & $\mathbf{0} \times$ \\
\hline \multicolumn{5}{|l|}{ GSS-Total } \\
\hline & $25 \sqrt{ }$ & $13 \sqrt{ }$ & $7 \sqrt{ }$ & $4 \sqrt{ }$ \\
\hline & $1 \times$ & $1 \times$ & $\mathbf{0} \times$ & $\mathbf{0} \times$ \\
\hline
\end{tabular}

\begin{tabular}{|c|c|c|c|c|}
\hline GSS-normative & Education & Male & $\begin{array}{l}\text { Income } \\
\text { growth }\end{array}$ & Job security \\
\hline setwage & $\sqrt{ }$ & $\sqrt{ }$ & & \\
\hline setprice & $\sqrt{ }$ & $\sqrt{ }$ & & \\
\hline lessreg & & $\sqrt{ }$ & & \\
\hline pricecon & $\sqrt{ }$ & & & \\
\hline aidindus & $\sqrt{ }$ & & & \\
\hline \multicolumn{5}{|l|}{ reqinfo } \\
\hline ownpower & & $\times$ & & \\
\hline ownsteel & $\sqrt{ }$ & & & \\
\hline ownbanks & $\sqrt{ }$ & & & \\
\hline \multicolumn{5}{|l|}{ econsys } \\
\hline buspow & & & $\sqrt{ }$ & \\
\hline privent & $\sqrt{ }$ & $\sqrt{ }$ & & \\
\hline \multicolumn{5}{|l|}{ profits2 } \\
\hline equal7 & & & & - \\
\hline letin & $\sqrt{ }$ & & & \\
\hline imports & $\sqrt{ }$ & & & \\
\hline excldimm & $\sqrt{ }$ & & & \\
\hline \multicolumn{5}{|l|}{ makejobs } \\
\hline cuthours & $\sqrt{ }$ & & & \\
\hline \multicolumn{5}{|l|}{ savejobs } \\
\hline jobsall & $\sqrt{ }$ & & & $\sqrt{ }$ \\
\hline equal3 & $\sqrt{ }$ & & $\sqrt{ }$ & - \\
\hline \multirow[t]{3}{*}{ anomia6 } & $\sqrt{ }$ & & $\sqrt{ }$ & $\sqrt{ }$ \\
\hline & $18 \sqrt{ }$ & $8 \sqrt{ }$ & $3 \sqrt{ }$ & $2 \sqrt{ }$ \\
\hline & $\mathbf{0} \times$ & $1 \times$ & $\mathbf{0} \times$ & $\mathbf{0} \times$ \\
\hline \multicolumn{5}{|l|}{$\begin{array}{l}\text { GSS-Pos } \\
\text { profits1 }\end{array}$} \\
\hline \multicolumn{2}{|l|}{ equal2 } & $\sqrt{ }$ & & - \\
\hline bosswrks & $\sqrt{ }$ & & & \\
\hline immunemp & $\sqrt{ }$ & & & \\
\hline immameco & $\sqrt{ }$ & $\sqrt{ }$ & & \\
\hline nafta2alt & $\sqrt{ }$ & & & \\
\hline \multicolumn{5}{|l|}{ newpast } \\
\hline \multicolumn{5}{|l|}{ newfutr } \\
\hline equal6 & & $\sqrt{ }$ & $\sqrt{ }$ & - \\
\hline anomia5 & $\sqrt{ }$ & & $\sqrt{ }$ & $\sqrt{ }$ \\
\hline \multirow[t]{3}{*}{ kidssol } & $\times$ & & $\sqrt{ }$ & $\sqrt{ }$ \\
\hline & $7 \sqrt{ }$ & $5 \sqrt{ }$ & $4 \sqrt{ }$ & $2 \sqrt{ }$ \\
\hline & $1 \times$ & $\mathbf{0} \times$ & 0 & $\mathbf{0} \times$ \\
\hline \multicolumn{5}{|l|}{ GSS-Total } \\
\hline & $25 \sqrt{ }$ & $13 \sqrt{ }$ & $7 \sqrt{ }$ & $4 \sqrt{ }$ \\
\hline & $1 \times$ & $1 \times$ & $\mathbf{0} \times$ & $\mathbf{0} \times$ \\
\hline
\end{tabular}

$\sqrt{ }=$ Coefficient significant at the $5 \%$ level and increases agreement with "economistic" views $x=$ Coefficient significant at the $5 \%$ level and decreases agreement with "economistic" views 
never does the opposite. The sign patterns for male gender, income growth, and job security also turn out as expected, but the effect of these variables on normative economic beliefs is markedly weaker than it is for positive economic beliefs.

Income, party, and ideology. A major negative finding in Caplan (2001) is that, contrary to popular belief, income level and conservatism do not make people think more like economists. In the SAEE, income level has little effect on beliefs. Ideology and party do have substantial effects, but they are orthogonal to "thinking like economists". Intuitively, economists endorse a mix of "extreme left-wing" views and "extreme right-wing" views.

The results for positive economic beliefs in the GSS are consistent with these earlier findings. Income level pushes in the economistic direction in one out of eleven questionsa result that could easily arise from chance. Republican party identification pushes in the economistic direction in four questions, but conservative ideology pushes in the opposite direction twice. For positive questions, right-wing thinking and economistic thinking look roughly orthogonal.

However, the results for income and political orientation sharply change when we switch from positive to normative economics (Table 7). Income has a noticeable effect on normative economic beliefs, and invariably works in an economistic direction. Similarly, there is a strong tendency for Republicans and conservatives to "think like economists" on normative questions. When we switch from positive to normative economic beliefs, economistic and right-wing thinking are hardly orthogonal; they seem to go hand in hand.

Why do the results for income, party, and ideology change so much when we switch from positive to normative questions? At least in hindsight, economists should have expected the results for income. Standard rational actor assumptions predict that the rich and poor will agree about policies' effects, but disagree along distributive lines about policies' desirability (Ricketts and Shoesmith 1992). This seems consistent with our data. Even though income has little effect on positive beliefs, it seems to change beliefs about desirable policies in a self-interested direction.

Although few economists will be surprised to learn that income affects normative economic beliefs, they should be. A large public opinion literature finds that objective self-interest predicts very little about political and social views (Mansbridge 1990; Sears and Funk 1990; Citrin and Green 1990; Sears et al. 1980). Our results for normative economic beliefs should therefore be seen not as a confirmation of the obvious, but as a notable counter-example to a well-established finding. Still, we should not overstate the strength of this counter-example. While income exerts a substantial effect on normative economic beliefs, it is far from their leading determinant. Compared to education, income has only a marginal effect.

Moving on to party and ideology, why would right-wing politics be orthogonal to the economic way of thinking for positive beliefs, but positively correlated for normative beliefs? The most likely explanation, in our view, is that our sets of positive and normative questions do not have the same mix of topics. In both the SAEE and the GSS, right-wing respondents are less antimarket, but more antiforeign. In the SAEE and the positive sub-sample of the GSS, the number of questions about markets and the number of questions about foreigners are comparable, leading to the orthogonality result. In the normative sub-sample of the GSS, however, questions about markets are several times more common than questions about foreigners. As a result, conservative Republicans and economic training push in the same direction more often than the reverse. 
Table 7 Sign patterns in the GSS: income, party, and ideology $\sqrt{ }=$ Coefficient significant at the $5 \%$ level and increases agreement with "economistic" views

$x=$ Coefficient significant at the $5 \%$ level and decreases agreement with "economistic" views

\begin{tabular}{|c|c|c|c|}
\hline GSS-normative & Income & Republican & Conservative \\
\hline setwage & $\sqrt{ }$ & $\sqrt{ }$ & $\sqrt{ }$ \\
\hline setprice & $\sqrt{ }$ & $\sqrt{ }$ & $\sqrt{ }$ \\
\hline lessreg & & $\sqrt{ }$ & $\sqrt{ }$ \\
\hline pricecon & $\sqrt{ }$ & $\sqrt{ }$ & $\sqrt{ }$ \\
\hline aidindus & $\sqrt{ }$ & $\sqrt{ }$ & \\
\hline \multicolumn{4}{|l|}{ reqinfo } \\
\hline \multicolumn{4}{|l|}{ ownpower } \\
\hline ownsteel & $\sqrt{ }$ & & $\sqrt{ }$ \\
\hline ownbanks & & & $\sqrt{ }$ \\
\hline \multicolumn{4}{|l|}{ econsys } \\
\hline buspow & & $\sqrt{ }$ & $\sqrt{ }$ \\
\hline privent & $\sqrt{ }$ & $\sqrt{ }$ & $\sqrt{ }$ \\
\hline profits 2 & & $\sqrt{ }$ & $\sqrt{ }$ \\
\hline equal7 & $\sqrt{ }$ & $\sqrt{ }$ & $\sqrt{ }$ \\
\hline \multicolumn{4}{|l|}{ letin } \\
\hline imports & & $\sqrt{ }$ & $x$ \\
\hline excldimm & & & $x$ \\
\hline makejobs & $\sqrt{ }$ & $\sqrt{ }$ & $\sqrt{ }$ \\
\hline cuthours & & & $\sqrt{ }$ \\
\hline savejobs & & $\sqrt{ }$ & $\sqrt{ }$ \\
\hline jobsall & $\sqrt{ }$ & $\sqrt{ }$ & $\sqrt{ }$ \\
\hline equal3 & $\sqrt{ }$ & $\sqrt{ }$ & $\sqrt{ }$ \\
\hline \multirow[t]{3}{*}{ anomia6 } & $\sqrt{ }$ & $\sqrt{ }$ & \\
\hline & $12 \sqrt{ }$ & $15 \sqrt{ }$ & $15 \sqrt{ }$ \\
\hline & $\mathbf{0} \times$ & $\mathbf{0} \times$ & $2 \times$ \\
\hline \multicolumn{4}{|l|}{ GSS-Pos } \\
\hline profits1 & & $\sqrt{ }$ & \\
\hline equal2 & & $\sqrt{ }$ & \\
\hline \multicolumn{4}{|l|}{ bosswrks } \\
\hline \multicolumn{4}{|l|}{ immunemp } \\
\hline \multicolumn{4}{|l|}{ immameco } \\
\hline nafta2alt & & & $x$ \\
\hline \multicolumn{4}{|l|}{ newpast } \\
\hline newfutr & & & $x$ \\
\hline equal6 & $\sqrt{ }$ & $\sqrt{ }$ & \\
\hline anomia5 & & $\sqrt{ }$ & \\
\hline \multicolumn{4}{|l|}{ kidssol } \\
\hline & $1 \sqrt{ }$ & $4 \sqrt{ }$ & $0 \sqrt{ }$ \\
\hline & $\mathbf{0} \times$ & $\mathbf{0} \times$ & \\
\hline \multicolumn{4}{|l|}{ GSS-Total } \\
\hline & $13 \sqrt{ }$ & $19 \sqrt{ }$ & $15 \sqrt{ }$ \\
\hline & $\mathbf{0} \times$ & & \\
\hline
\end{tabular}




\section{Discussion}

Existing literature finds little evidence of a connection between positive and normative economic beliefs. But if normative economic beliefs respond to a large set of noisily measured positive economic beliefs, regressing normative beliefs on a handful of positive economic beliefs will yield many false negatives. As a robustness check on the standard results, we combined two data sets, the SAEE and the GSS, to see whether positive and normative economic beliefs have similar underlying structures.

If the standard result were correct, we would expect the determinants of these two kinds of beliefs to basically be orthogonal. Instead, we find that positive and normative beliefs have important determinants in common. Education is by far the strongest predictor of both classes of beliefs; party identification and ideology are also consistently influential. Using $p_{\lambda}$ statistics to measure the "overall importance" of independent variables on sets of dependent variables confirms that variables with strong effects on positive economics also tend to have strong effects on normative economics, and vice versa. Furthermore, when we go beyond statistical significance, and check whether the sign patterns on positive and normative beliefs match up, they do.

Admittedly, our findings shed little light on the mechanism that connects positive and normative economic beliefs. Economists tend to share Friedman's presumption that positive beliefs inform normative beliefs. But our data cannot rule out reverse causation. People could start with normative beliefs, and "reason" backwards to the positive beliefs that best support their position (Taber and Lodge 2006; Tetlock 2003).

On balance, though, we suspect that education largely reflects positive-to-normative causation, while party and ideology largely reflect normative-to-positive causation. Education does try to inculcate some morals-especially tolerance (Hainmueller and Hiscox 2007). But educators' main goals, at least in Western countries, are providing information and teaching better thinking habits. The more information people have, and the better their thinking habits, the less subject they are to the systematically biased beliefs about economics that Caplan (2007: 30-48) catalogs. This in turn makes the welleducated more skeptical about policies like price controls, protectionism, and guaranteed jobs.

For party and ideology, however, the normative-to-positive direction is much more plausible. Politicians and activists clearly try to sway values. While they do provide some information, they often actively encourage bad thinking habits like confirmation bias and groupthink (Glaeser and Sunstein 2009; Cowen 2005). As a result, partisanship and ideology make it easy for people to believe that the economic policies they favor have conveniently good consequences. ${ }^{13}$

Of course, positive-to-normative and normative-to-positive causation are not the only possible mechanisms at work. Other, more complex accounts of the positive-normative connection exist. Many scholars - and even Friedman himself-may have implicitly been thinking in terms of coherence or "reflective equilibrium" between positive and normative beliefs (Rawls 1971; Harsanyi 1969; Goodman 1960). Switching to a coherentist framework raises further issues. Agents might seek psychological coherence motivated by cognitive dissonance, rather than logical or epistemic coherence (Cooper 2007).

\footnotetext{
${ }^{13}$ Another potentially fruitful way to test for the direction of causation is to control for respondents' religion. Any effect of religious doctrine and activity on positive economic beliefs presumably reflects normative-topositive causation rather than the other way around. The GSS measures religious doctrine and activity, but the SAEE unfortunately does not, so we leave this issue for future research. We thank Bill Shughart, for suggesting this line of inquiry.
} 
Our own view is compatibilist. Some scholars focus on causation, others on coherence. Regardless of the framework, though, there is a continuum between the pure positive-tonormative and pure normative-to-positive theories of belief formation-and responses to any particular question can potentially land anywhere on the continuum. On the other hand, if positive and normative beliefs were truly unrelated, both the causal and the coherentist approaches would both be equally misguided.

\section{Conclusion}

Common sense tells us that beliefs about how the economy works and beliefs about what policies are good are inherently connected. To grasp the effects of congestion pricing, for example, usually suffices to make people favor congestion pricing. However, most studies have found little evidence to support the common sense view (Blinder and Krueger 2004; Fuchs et al. 1998; Fuchs 1996). There almost seems to be a firewall between positive and normative economic beliefs.

This paper performs a novel robustness check on this result. It first estimates the responsiveness of a diverse set of positive and normative economic beliefs to respondents' characteristics. Then it separately aggregates the results for the two categories of belief to compare their underlying structures.

These structures have striking parallels. Education is by far the strongest predictor of positive and normative beliefs alike. Positive and normative beliefs have four out of their six strongest predictors in common. The correlation between the $p_{\lambda}$ vectors for all the positive beliefs and all the normative beliefs is an impressive 0.65 . The sign patterns are right: education, being male, income growth, and job security make people "think like economists" both positively and normatively. While these findings are not decisive proof that positive and normative economic beliefs are causally connected, they make the plausible hypothesis that they are casually connected much more probable.

But our evidence does more than undermine the view that positive and normative are unrelated. We also find two major disanalogies between positive and normative economics. First, unlike positive economic beliefs, normative economic beliefs turn out to be moderately sensitive to income. There is a kernel of truth in the view that the rich like economists' message —or at least dislike it less than the poor do. Second, Republican party identification and conservative ideology push normative economic beliefs in an economistic direction, but are roughly orthogonal to positive economic beliefs. In our judgment, the asymmetric effect of party and ideology on normative and positive economics is an artifact of question composition, stemming from the relatively small question of normative questions about the international economy. Future research should examine this issue further.

It may be difficult to find specific positive beliefs that strongly predict specific normative beliefs, but it is premature to conclude that positive and normative economics have little do with each other. In fact, it is quite likely that the joint effect of all positive economic beliefs on all normative economic beliefs is substantial. Perhaps, to take an easy example, education changes a whole array of positive beliefs, which in turns changes a whole array of normative beliefs. Indeed, while other explanations remain, this is the most straightforward interpretation of the available data. 
Acknowledgements We would like to thank Robin Hanson and two anonymous referees for helpful discussion. Geoffrey Lea provided excellent research assistance. The standard disclaimer applies.

\section{References}

Alston, R., Kearl, J., \& Vaughan, M. (1992). Is there a consensus among economists in the 1990's? American Economic Review, 82(2), 203-209.

Blendon, R., Benson, J., Brodie, M., Morin, R., Altman, D., Gitterman, D., Brossard, M., \& James, M. (1997). Bridging the gap between the public's and economists' views of the economy. Journal of Economic Perspectives, 11(3), 105-188.

Blinder, A., \& Krueger, A. (2004). What does the public know about economic policy, and how does It know it? Brookings Papers on Economic Activity, 1, 327-387.

Caplan, B. (2001). What makes people think like economists? Evidence on economic cognition from the Survey of Americans and Economists on the Economy. Journal of Law and Economics, 44(2), 395426.

Caplan, B. (2002a). Systematically biased beliefs about economics: robust evidence of judgemental anomalies from the Survey of Americans and Economists on the Economy. Economic Journal, 112(479), 433-458.

Caplan, B. (2002b). Sociotropes, systematic bias, and political failure: reflections on the Survey of Americans and Economists on the Economy. Social Science Quarterly, 83(2), 416-435.

Caplan, B. (2006). How do voters form positive economic beliefs? Evidence from the Survey of Americans and Economists on the Economy. Public Choice, 128(3/4), 367-381.

Caplan, B. (2007). The myth of the rational voter: why democracies choose bad policies. Princeton: Princeton University Press.

Caplan, B., \& Miller, S. (2010). Economic beliefs, intelligence, and ability bias: evidence from the General Social Survey. Unpub ms. http://www.gmu.edu/departments/economics/bcaplan/iqbeliefej.doc.

Citrin, J., \& Green, D. (1990). The self-interest motive in American public opinion. Research in Micropolitics, $3,1-28$.

Cooper, J. (2007). Cognitive dissonance: 50 years of a classic theory. Sage Publications: London.

Cowen, T. (2005). Self-deception as the root of political failure. Public Choice, 124(3-4), 437-451.

Friedman, M. (1953). The methodology of positive economics. In M. Friedman (Ed.), Essays in positive economics (pp. 3-43). Chicago: University of Chicago Press.

Foss, D. (1982). A discourse on semantic priming. Cognitive Psychology, 14, 590-607.

Fuller, D., \& Geide-Stevenson, D. (2003). Consensus among economists: revisited. Journal of Economic Education, 34(4), 369-387.

Fuchs, V. (1996). Economics, values, and health care reform. American Economic Review, 86(1), 1-24.

Fuchs, V., Krueger, A., \& Poterba, J. (1998). Economists' views about parameters, values, and policies: survey results in labor and public economics. Journal of Economic Literature, 36(3), 1387-1425.

General Social Survey (2008). http://www.norc.org/GSS+Website/.

Glaeser, E., \& Sunstein, C. (2009). Extremism and social learning. Journal of Legal Analysis, 1, $263-324$.

Goodman, N. (1960). The way the world is. Review of Metaphysics, 14(1), 48-56.

Hainmueller, J., \& Hiscox, M. (2007). Educated preferences: explaining attitudes toward immigration in Europe. International Organization, 61, 399-442.

Harsanyi, J. (1969). Rational-choice models of political behavior vs. functionalist and conformist theories. World Politics, 21(4), 513-538.

Howson, C., \& Urbach, P. (1989). Scientific reasoning: the Bayesian approach. LaSalle: Open Court.

Krosnick, J., \& Alwin, D. (1987). An evaluation of a cognitive theory of response-order effects in survey measurement. Public Opinion Quarterly, 51, 201-219.

Maddala, G. S. (1977). Econometrics. New York: McGraw-Hill.

Mansbridge, J. (Ed.) (1990). Beyond self-interest. Chicago: University of Chicago Press.

Miller, S. (2009). Economic bias and ideology: evidence from the General Social Survey. Journal of Private Enterprise, 25(1), 31-49.

Rawls, J. (1971). A theory of justice. Cambridge: Harvard University Press.

Ricketts, M., \& Shoesmith, E. (1992). British economic opinion: positive science or normative judgment? American Economic Review, 82(2), 210-215.

Sears, D., \& Funk, C. (1990). Self-interest in Americans' political opinions. In J. Mansbridge (Ed.), Beyond self-interest (pp. 147-170). Chicago: University of Chicago Press.

Sears, D., Lau, R., Tyler, T., \& Allen, H. (1980). Self-interest vs. symbolic politics in policy attitudes and Presidential voting. American Political Science Review, 74(3), 670-684. 
Taber, C., \& Lodge, M. (2006). Motivated skepticism in the evaluation of political beliefs. American Journal of Political Science, 50(3), 755-769.

Tetlock, P. (2003). Thinking the unthinkable: sacred values and taboo cognitions. Trends in Cognitive Science, 7(7), 320-324.

Washington Post, Kaiser Family Foundation, Harvard University Survey Project (1996). Survey of Americans and Economists on the Economy. October 16, \#1199. http://www.kff.org/kaiserpolls/ 1199-econgen.cfm.

Whaples, R. (2006). Do economists agree on anything? Yes! The Economists' Voice, 3(9). http://www. bepress.com/ev/vol3/iss9/art1. 